\title{
Evaluation of Organic Pollution by Palmer's Algal Genus Index and Physico-chemical Analysis of Vaigai River at Madurai, India
}

\author{
S.David Noel, M.R.Rajan* \\ Department of Biology, Gandhigram Rural Institute-Deemed University, India
}

Copyright (C) 2015 Horizon Research Publishing All rights reserved.

\begin{abstract}
Evaluation of organic pollution by Palmer's Algal Genus Index and physico-chemical and biological characters of Vaigai River water of India and its suitability for drinking and irrigation purposes was carried out. The sampling points were selected on the basis of their importance. Analysis of physico-chemical parameters like $\mathrm{pH}$, electrical conductivity, total dissolved solids, dissolved oxygen, chloride, sulphate, total hardness, calcium, magnesium, and sodium, potassium has been carried out. Organic pollution was assessed by employing Palmers algal pollution index. From the above analysis it is observed that all the sampling points are biologically contaminated due to good supply of nutrients into the river Vaigai and the high physico-chemical parameters supported enrichment of river water with nutrients.
\end{abstract}

Keywords Vaigai River, Physico-chemical Parameters, Bureau of Indian Standard, Palmers Algal Pollution Index, Eutrophication

\section{Introduction}

River water is one of the most important and widely distributed natural resources which is considered as supplemental resource to meet the domestic, agricultural and industrial requirements [1]. Such rivers are polluted by the addition of organic material such as sewage, food waste or farm effluent, bacteria and other micro-organism feed on organic matter. Since most of the rivers end up in oceans, the coastal region of India faces a variety of problems due to the contaminated discharges of the rivers flowing through a number of densely populated regions of the country. Many of the coastal areas have problems connected with water quality due to urban waste discharge [2]. The chemical wastes from industrial process are sometimes accidentally discharged into river Examples of such pollutants include cyanide, zinc, lead, copper, cadmium, and mercury [3]. These substances may enter the water in such high concentration and ultimately kills fish and other animals[4]. Contamination of river water results in poor drinking water quality, loss of water supply, high cleanup cost, high cost in alternative water supply and potential health hazards. Almost 70\% of water in India has become polluted due to the discharge of domestic sewage and industrial effluents into natural water sources such as rivers and streams as well as lakes [5] Of the environmental elements, water is the most affected as the big industries are usually situated on the river banks and due to continuous receiving of the effluents the toxicity of these river water increases day by day. The environmental pollution created by the industries has now become a burning issue of the nation. Vaigai river receives huge quanity sewage results in organic pollution which encourages large number of disease spreading organisms. Moreover human excreta deposited on the banks are washed in to the basin due to drainage causing ecological nuisance. Based on above considerations and lack of organic and inorganic pollution assessment in Vaigai river, the present study was conducted to evaluate the level of pollution in Vaigai river by biological and chemical methods.

\section{Materials and Methods}

\subsection{Study Site}

The Vaigai river is situated in Madurai between longitude $9^{\circ} 35^{\prime}$ to $12^{\circ} 30^{\prime}$ North and $77^{\circ} 07^{\prime}$ to $79^{\circ} 25^{\prime}$ East in which is one of the important rivers in Tamil Nadu state of southern India. The river has a heavy flow of water during September to December at north east monsoon.

\subsection{Sampling and Laboratory Studies}

Water samples were collected from seven selected sampling sites namely Arapalayam, Kochadai, Sellur, Kuruvikaran Salai, Victoria bridge, Theppakulam, and Viraganur during pre-monsoon and monsoon season. (Table-1). Water samples were collected in sterilized clean high density polythene bottles. The physico-chemical parameters of river water like, $\mathrm{pH}$, electrical conductivity, total dissolved solids, dissolved oxygen, chloride, sulphate, 
total hardness, calcium, magnesium, sodium and potassium were analyzed as per the standard methods [6] and the results were compared with BIS [7] (Table-2) for potable water. Micro plankton study of the river was done by taking twenty liters of water and filtering it through a plankton net cloth no. 20 and was collected in one liter wide mouth plastic container. The samples were identified under the research microscope and the counting was done by Lackey's drop method. Algal Generic [8] was employed to determine the organic pollution.

Table 1. Name and the station code of water samples collected along Vaigai River in Madurai

\begin{tabular}{|c|c|c|}
\hline S.No & Station Code & Name of the Station \\
\hline 1 & S1 & Arapalayam \\
\hline 2 & S2 & Kochadai \\
\hline 3 & S3 & Sellur \\
\hline 4 & S4 & Kuruvikaran Salai \\
\hline 5 & S5 & Theppakulam \\
\hline 6 & S6 & Viraganur \\
\hline 7 & S7 & \\
\hline
\end{tabular}

Table 2. Standard parameters for water characterization

\begin{tabular}{|c|c|c|}
\hline & Parameters & $\begin{array}{c}\text { BIS } \\
\text { Values }\end{array}$ \\
\hline 1 & $\mathrm{pH}$ & $6.5-8.5$ \\
\hline 2 & $\begin{array}{l}\text { Electrical Conductivity } \mathrm{mS} / \mathrm{cm} \\
\text { (milli siemens per centimeter) }\end{array}$ & $\begin{array}{c}750-225 \\
0\end{array}$ \\
\hline 3 & Total Dissolved Solids $\mathrm{mg} \mathrm{l}^{-1}$ (milligram per litre) & 500 \\
\hline 4 & Dissolved oxygen $\mathrm{mg} \mathrm{l}^{-1}$ (milligram per litre) & 8 \\
\hline 5 & Chloride $\mathrm{mg} \mathrm{l}^{-1}$ (milligram per litre) & 250 \\
\hline 6 & Sulphate $\mathrm{mg} \mathrm{l}^{-1}$ (milligram per litre) & 200 \\
\hline 7 & Total Hardness $\mathrm{mg} \mathrm{l}^{-1}$ (milligram per litre) & 300 \\
\hline 8 & Potassium $\mathrm{mg} \mathrm{l}^{-1} \quad$ (milligram per litre) & 12 \\
\hline 9 & Calcium $\mathrm{mg} \mathrm{l}^{-1}$ (milligram per litre) & 30 \\
\hline 10 & Magnesium $\mathrm{mg} \mathrm{l}^{-1}$ (milligram per litre) & 75 \\
\hline 11 & Sodium $\mathrm{mg} \mathrm{l}^{-1}$ (milligram per litre) & 100 \\
\hline
\end{tabular}

BIS- Bureau of Indian standard

\section{Results and Discussion}

The water quality analysis of river water samples have been carried out for $\mathrm{pH}$, electrical conductivity, TDS, Dissolved oxygen, Chloride, Sulphate, Total hardness, K, Ca, $\mathrm{Mg}$ and $\mathrm{Na}$ etc., The Physico-chemical parameters of river water is presented in table-3. $\mathrm{pH}$ value of river water samples varied between 8.34 to 7.76 and 7.34 to 6.4 during pre and monsoon season respectively. The $\mathrm{pH}$ value of all the samples are within the permissible limit as per BIS (1983) (Table-2). Electrical conductivity varied between 2312 to 2122 and 2012 to $1878 \mu \mathrm{mhos} / \mathrm{cm}$ in pre and monsoon season and found within the limits prescribed by BIS. Total dissolved solids indicate the salinity behavior of river water. Dissolved oxygen is important parameter in water quality assessment and reflects the physical and biological processes prevailing in the water. The DO values indicate the degree of pollution in water bodies. It varied from 13 to $7 \mathrm{mg} \mathrm{l}^{-1}$ and 7 to $5 \mathrm{mg} \mathrm{l}^{-1}$ in pre and monsoon respectively. The sampling station S1(Table-1) showed low DO during monsoon similar result was observed in S6 also whereas S7 showed low DO in both the season. Similar findings were reported by [9] in river Ganga. The chloride concentration serves as an indicator of pollution by sewage. People accustomed to higher chloride in water are subjected to laxative effects [10]. In the present analysis, Chloride content of the water samples was in the range of 256 to $243 \mathrm{mg} \mathrm{l}^{-1}$ and 242 to $189 \mathrm{mg} \mathrm{l}^{-1}$ in pre and monsoon season respectively. The values are above the limit during pre-monsoon whereas within the limit during monsoon in all the sampling stations. The similar pattern also was observed other chemical parameters also. It may be due to seepage from sewage drainage in nearby localities.

Table 3. Physico-chemical parameters river water

\begin{tabular}{|c|c|c|c|c|c|c|c|c|c|c|c|c|c|c|}
\hline $\begin{array}{c}\text { Physico- Chemical } \\
\text { Parameters }\end{array}$ & \multicolumn{2}{|c|}{$\mathrm{S} 1$} & \multicolumn{2}{|c|}{$\mathrm{S} 2$} & \multicolumn{2}{|c|}{$\mathrm{S} 3$} & \multicolumn{2}{|c|}{ S4 } & \multicolumn{2}{|c|}{ S5 } & \multicolumn{2}{|c|}{ S6 } & \multicolumn{2}{|c|}{ S7 } \\
\hline & $\begin{array}{l}\text { Pre } \\
\text { Mon }\end{array}$ & Mon & $\begin{array}{l}\text { Pre } \\
\text { Mon }\end{array}$ & Mon & $\begin{array}{l}\text { Pre } \\
\text { Mon }\end{array}$ & Mon & $\begin{array}{l}\text { Pre } \\
\text { Mon }\end{array}$ & Mon & $\begin{array}{l}\text { Pre } \\
\text { Mon }\end{array}$ & Mon & $\begin{array}{l}\text { Pre } \\
\text { Mon }\end{array}$ & Mon & $\begin{array}{l}\text { Pre } \\
\text { Mon }\end{array}$ & Mon \\
\hline $\mathrm{pH}$ & 8.34 & 7.34 & 8.10 & 7.28 & 7.87 & 7.11 & 7.93 & 7.56 & 8.45 & 7.97 & 7.46 & 7.23 & 7.76 & 6.45 \\
\hline $\begin{array}{c}\text { Electrical } \\
\text { Conductivity } \\
(\mathrm{mS} / \mathrm{cm})\end{array}$ & 2312 & 2012 & 2134 & 2031 & 2551 & 2323 & 2157 & 2034 & 2257 & 2163 & 2315 & 2268 & 2122 & 1878 \\
\hline $\begin{array}{c}\text { Total Dissolved } \\
\text { Solids } \mathrm{mg} \mathrm{l}^{-1}\end{array}$ & 498 & 342 & 519 & 426 & 470 & 397 & 534 & 436 & 583 & 418 & 460 & 396 & 579 & 463 \\
\hline $\begin{array}{l}\text { Dissolved oxygen } \\
\mathrm{mg} \mathrm{l}^{-1}\end{array}$ & 13 & 7 & 10 & 8 & 9 & 8 & 14 & 10 & 12 & 9 & 8 & 7 & 7 & 5 \\
\hline Chloride $\mathrm{mg} \mathrm{l}^{-1}$ & 256 & 242 & 274 & 284 & 196 & 264 & 306 & 226 & 286 & 234 & 254 & 197 & 273 & 189 \\
\hline Sulphate $\mathrm{mg} \mathrm{l}^{-1}$ & 213 & 143 & 267 & 149 & 245 & 125 & 256 & 104 & 256 & 132 & 267 & 125 & 235 & 112 \\
\hline Calcium $\mathrm{mg} \mathrm{l}^{-1}$ & 85 & 30 & 85 & 32 & 96 & 47 & 87 & 53 & 87 & 26 & 93 & 49 & 82 & 21 \\
\hline Magnesium mg $1^{-1}$ & 45 & 28 & 85 & 24 & 78 & 27 & 76 & 24 & 98 & 19 & 74 & 25 & 68 & 23 \\
\hline
\end{tabular}

Pre Mon -Premonsoon, Mon - Monsoon $\mathrm{mS} / \mathrm{cm}$ - milli siemens per centimeter, $\mathrm{mg} \mathrm{l}^{-1}$-milligram per litre 
Table 4. Algal Genus Pollution Index (Palmer 1969)

\begin{tabular}{|c|c|c|c|c|}
\hline S.no & Genus & Index & Genus & Index \\
\hline 1 & Anacystis & 2 & Micractinium & 1 \\
\hline 2 & Ankistrodesmus & 4 & Navicula & 3 \\
\hline 3 & Chlamydomonas & 3 & Nitzschia & 3 \\
\hline 4 & Chlorella & 1 & Oscillatoria & 5 \\
\hline 5 & Closterium & 1 & Pandorina & 1 \\
\hline 6 & Cyclotella & 5 & Phacus & 2 \\
\hline 7 & Euglena & 1 & Scenedesmus & 1 \\
\hline 8 & Gomphonema & 1 & Stigeoclonium & 4 \\
\hline 9 & Lepocinclis & Syndra & 2 \\
\hline 10 & Melosira & 1 & & 2 \\
\hline
\end{tabular}

Table 5. Algal distribution in different locations of Vaigai River

\begin{tabular}{|c|c|c|c|c|c|c|c|c|c|c|c|c|c|c|}
\hline \multirow[t]{2}{*}{ Algal Genera } & \multicolumn{2}{|c|}{ S1 } & \multicolumn{2}{|c|}{ S2 } & \multicolumn{2}{|c|}{ S3 } & \multicolumn{2}{|c|}{ S4 } & \multicolumn{2}{|c|}{ S5 } & \multicolumn{2}{|c|}{ S6 } & \multicolumn{2}{|c|}{ S7 } \\
\hline & $\begin{array}{c}\text { Pre } \\
\text { Mon } \\
\end{array}$ & Mon & $\begin{array}{c}\text { Pre } \\
\text { Mon }\end{array}$ & Mon & $\begin{array}{l}\text { Pre } \\
\text { Mon } \\
\end{array}$ & Mon & $\begin{array}{c}\text { Pre } \\
\text { Mon }\end{array}$ & Mon & $\begin{array}{c}\text { Pre } \\
\text { Mon } \\
\end{array}$ & Mon & $\begin{array}{c}\text { Pre } \\
\text { Mon }\end{array}$ & Mon & $\begin{array}{c}\text { Pre } \\
\text { Mon }\end{array}$ & Mon \\
\hline Anacystis & 1 & - & 1 & - & - & 1 & 1 & 1 & - & - & 1 & - & 1 & - \\
\hline Ankistrodesmus & - & 2 & - & 2 & - & 2 & - & 2 & - & 2 & - & 2 & - & 2 \\
\hline Chlamydomonas & - & - & 4 & - & 4 & - & 4 & - & - & 4 & 4 & - & 4 & - \\
\hline Chlorella & 3 & - & - & 3 & - & - & - & - & 3 & - & - & 3 & - & - \\
\hline Closterium & 1 & - & 1 & - & - & 1 & 1 & 1 & - & - & 1 & - & - & 1 \\
\hline Cyclotella & - & - & 1 & & - & & - & - & - & 1 & - & 1 & - & - \\
\hline Euglena & - & 5 & - & 5 & 5 & - & - & 5 & 5 & - & - & - & 5 & - \\
\hline Gomphonema & 1 & - & - & - & - & 1 & 1 & 1 & - & - & 1 & 1 & - & 1 \\
\hline Lepocinclis & - & 1 & 1 & - & 1 & 1 & 1 & - & - & - & 1 & - & - & 1 \\
\hline Melosira & 1 & - & - & - & - & 1 & 1 & - & - & 1 & - & - & 1 & - \\
\hline Micractinium & 1 & 1 & 1 & - & - & 1 & 1 & - & - & - & - & - & - & 1 \\
\hline Navicula & - & - & 3 & 3 & - & - & 3 & - & - & 3 & - & - & 3 & - \\
\hline Nitzschia & 3 & - & - & - & - & - & - & - & & 3 & - & - & 3 & - \\
\hline Oscillatoria & 4 & 4 & 4 & - & - & 4 & 4 & 4 & - & - & 4 & - & 4 & - \\
\hline Pandorina & - & - & 1 & 1 & - & 1 & - & - & 1 & - & - & - & - & 1 \\
\hline Phacus & 2 & 2 & - & - & 2 & - & 2 & - & - & - & 2 & 2 & - & 2 \\
\hline Phormidium & - & - & 1 & 1 & 1 & - & 1 & 1 & 1 & - & 1 & - & - & 1 \\
\hline Scenedesmus & 4 & - & - & - & 4 & - & - & 4 & 4 & - & - & 4 & - & 4 \\
\hline Stigeoclonium & - & - & 2 & - & - & 2 & 2 & - & 2 & - & 2 & - & 2 & - \\
\hline Synedra & 2 & 2 & - & - & 2 & - & 2 & - & - & 2 & - & 2 & - & 2 \\
\hline Total & 23 & 17 & 20 & 15 & 19 & 15 & 24 & 19 & 16 & 16 & 17 & 15 & 23 & 16 \\
\hline
\end{tabular}

If the pollution index score is 20 or more, the score is evidence of high organic pollution. A score of 15-19 indicates probable organic pollution. Lower scores usually indicate less organic pollution.0-1 indicates lack of organic pollution.

In the present study the distribution pattern of algal flora in various sampling points of Vaigai River is given in table-5. Palmers algal genera pollution index is employed in all the sampling points (Table-4). Certain plankton genera are present in common which include Chlorophceae like
Scenedesmus, Ankistrodesmus, Chlorella,Selenastrum, Myxop hyceae such as Oscillatoria and Bacillariophyceae Synedra, Melosira, Cyclotella, Navicula and protozoans like Euglena. Sampling points S1, S2, S4, S7showed high organic pollution during premonsoon Algae such as Chlorella, Scenedesmus, Nitzchia, Oscillattoria were present in the river water which indicate organic pollution [11] and rest of the sampling points show probable organic pollution during monsoon whereas S3 showed probable organic pollution during premonsoon and monsoon (Fig 1). 


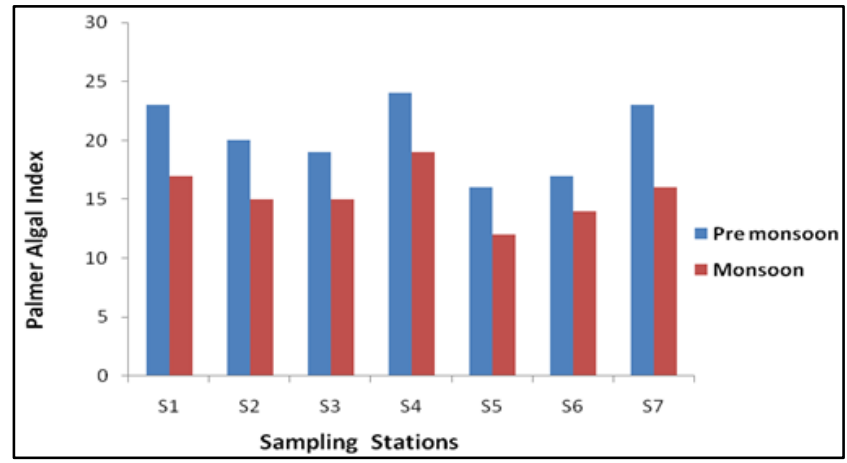

Figure 1. Palmer's Algal Genus Index indicating level of organic pollution at different stations of Vaigai River

\section{Conclusions}

From the study it is inferred that the Vaigai river receives a load of nutrients from surrounding lands as well as from anthropogenic activities, bathing and washing that led to severe contamination followed by eutrophication hence it is suggested to exercise all the necessary precaution before the water is used for drinking and irrigation, otherwise, it may lead to much adverse health effect.

\section{REFERENCES}

[1] G.Vanitha, M.Shunmugavelu. Hydrochemical assessment of
Vaigai river water in India, International Journal of Environmental Sciences.Vol.2, No 4, 2012.

[2] K. Trivedi Khatavkar, A.Y. Kulkarni and A.C.Shrotri. Ecology and pollution of River Krishna in Maharashtra, Ministry of Environment and Forests, Government of India.1990.

[3] N. Rajmohan. and L. Elango. Nutrient chemistry of groundwater in an intensively irrigated region of southern India, Environmental Geology.Vol.47.820-830.2005.

[4] B. S. Muhammad Barzani Gasim, Ismail Ekhwan Toriman, Sujaul Islam Mir and Tan Choon Chek, A Physico- Chemical Assessment of the Baber River, Pahang, Malaysia, Global Journal of Environmental Research. Vol.1.No.1.07-11, 2007.

[5] R. Radhakrishnan, K. Dharmaraj, B.D. Ravithakur,J.Environmental Biology.Vol.28. No.1 105, 2007.

[6] Standard Methods for the Examination of Water and Wastewater APHA-AWWA- WPCF, Washington D.C. 1998.

[7] BIS, Standards for water for drinking and other purposes, Bureau of Indian standards publication. New Delhi.1983.

[8] C. M. Palmer. Keys to water quality indicative organisms (South Eastern United States) Dept. of Interior, Federal Water Pollution Control Administration, Ohio, U.S.A. 1968.

[9] B.N.Singh, S. Rai,. Physico-chemical studies of Ganga river at Varanasi. J. Env. Poll.Vol. 6.43-46.1999.

[10] A. Gupta , C,K.Kumar, G.Ojha, and Singh. J Environmental Science and Engineering, Vol. 46.No.1.74-78. 2004.

[11] N.D. Kamat, Topics in Algae, Saikripa Prakashan, New Delhi. 1982. 